\title{
Plasma membrane and cell wall properties of an aspen hybrid (Populus tremula $\times$ tremuloides) parenchyma cells under the influence of salt stress
}

\author{
Aleksandra Muszyńska • Katarzyna Jarocka • \\ Ewa U. Kurczynska
}

Received: 8 January 2013/Revised: 5 January 2014/ Accepted: 8 January 2014/Published online: 30 January 2014 (C) The Author(s) 2014. This article is published with open access at Springerlink.com

\begin{abstract}
The effect of salinity on cell turgor, plasma membrane permeability and cell wall elasticity has been measured in petioles of an aspen hybrid using the cell pressure probe. Control plants were grown in soil without the addition of $\mathrm{NaCl}$ and treated plants were grown in soil with $50 \mathrm{mM}$ of $\mathrm{NaCl}$ for $1,2,3$ and 4 weeks. In parenchyma cells from Populus tremula $\times$ tremuloides petioles with an increased level of $\mathrm{NaCl}$ in the soil: (a) turgor pressure was reduced after 1 week of treatment but afterward it was similar to untreated plants, (b) the value of elastic modulus of the cell walls increased, and (c) hydraulic conductivity of the plasma membrane of treated plants decreased in comparison to untreated ones. No histological differences and distribution of JIM5 antibody between the petioles of plants grown under salinity and the untreated were found. In cell walls of parenchyma and collenchyma from plants grown under salinity, the presence of pectic epitopes recognized by JIM7 antibodies was increased in comparison to the control plants. The obtained results indicate that under salt stress the permeability of water through plasma membrane is disturbed, cell
\end{abstract}

Communicated by E. Schleiff.

Electronic supplementary material The online version of this article (doi:10.1007/s11738-014-1490-3) contains supplementary material, which is available to authorized users.

A. Muszyńska · K. Jarocka · E. U. Kurczynska $(\bowtie)$

Laboratory of Cell Biology, University of Silesia,

ul. Jagiellońska 28, 40-032 Katowice, Poland

e-mail: euk@us.edu.pl

\section{A. Muszyńska}

Leibniz-Institut für Pflanzengenetik und

Kulturpflanzenforschung (IPK), Corrensstraße 3,

06466 Gatersleben, Germany walls became more rigid but the turgor pressure did not change.

Keywords Elastic modulus of cell wall $\cdot$ Hydraulic conductivity of plasma membrane $\cdot$ JIM5 - JIM7 - Salt stress - Turgor pressure

\section{Introduction}

Salt stress is one of the major abiotic stress factors that affect growth of plants worldwide. High salinity influences plants on every stage of their development and injurious effect is dependent on species, its age and interactions with other environmental factors (Munns and Tester 2008; Wrochna et al. 2006; Zhu 2002). In most saline environments, sodium chloride is the main salt compound that inhibits cell division and expansion. Too high concentrations of chloride and sodium ions in soil cause reduction of water available for plants in the first phase of salt stress (Yeo et al. 1991). This stage is caused by the increased osmotic forces that retain water in the soil solution and cause reduction of water potential in the soil. Related to these changes, reduced water absorption by plants causes reduction in turgor pressure and inhibition of cell elongation (Hock and Elstner 2004). Salt stress also causes great changes in ion balance induced by reduced $\mathrm{K}^{+}, \mathrm{Ca}^{2+}$, and $\mathrm{NO}_{3}{ }^{-}$uptake from the soil (Niu et al. 1995). Furthermore, sodium ions are competing for binding sites in the root cells with potassium ions, whereas calcium ions are removed due to the ion exchange which results in their deficit in a plant (Cramer and Läuchli 1986). Sodium chloride also causes ionic stress that is related to ion balance in every single cell in the plant body (Hasegawa et al. 2000). 
The influence of salinity on plant cell ultrastructure, physiology and expression of genes is well documented, but the influence of salt stress on the cell wall is still not fully understood. The cell wall is a dynamic organellum that changes under the influence of different stimuli, both from the outer and inner environment, which affect the fate of the cells, tissues and even whole organisms. In previous studies, the effect of salt stress on plant cell wall displayed very important changes in its structure and composition. High salinity caused both quantitative and qualitative modifications of the cell wall components. It was shown that salt stress causes changes in hemicelluloses, cellulose (Zhong and Laüchli 1993) and pectin content in the cell walls (McCann et al. 1994). Cell wall protein content including arabinogalactan proteins also depends on salinity (Lamport et al. 2006). All these chemical changes can have influence on physical properties of plant cell walls, which are considered to be one of the most important physiological mechanisms of plant adapting to water stress (Martínez et al. 2007). One of the parameters describing physical properties of the cell wall is elastic modulus, the increase of which would contribute to maintain the cell turgor pressure and cell volume during the salt stress, but unfortunately there are only a few reports on direct effect of salt stress on elastic modulus of a single plant cell wall (Azaizeh et al. 1992; Bastías et al. 2004). One of these is the study carried out on seedlings of monocot, Zea mays where values of elastic modulus ranged between 0.8 and $2 \mathrm{MPa}$ in control and 0.8 and 3.6 MPa in cells from salt-stressed plants, so there was no significant change in this parameter between control plants and those treated with salt (Azaizeh et al. 1992). The information about the influence of long-lasting salt stress on dicotyledones, especially perennial plants is still scarce. Other studies on the impact of salt stress on physical properties of cell walls restrain to bulk elastic moduli which are mean values for all cells in the tissues (Pérez-López et al. 2010). Information about the influence of salinity on the properties of individual cell walls is still lacking.

Sodium and chloride ions also cause changes in interactions of water particles which affect their interactions with proteins and can affect the activity of aquaporins (Chrispeels and Maurel 1994). Proper functioning of water channels can be easily disturbed by abiotic stress factors like low temperature (Lee et al. 2004), heavy metals (Przedpełska et al. 2008), drought (Luu and Maurel 2005) and oxygen deprivation (Tournaire-Roux et al. 2003). Studies carried out on algae Valonia showed that also turgor and osmotic pressure influenced hydraulic conductivity of plasma membrane (Dainty and Ginzburg 1964). All these factors can regulate the activity of aquaporins on the stage of transcription, translation or by the displacement of water channels in the cell membranes or finally by the reversible phosphorylation of these proteins (Boursiac et al. 2005). The best parameter which describes the activity of water channels in the plant cell membranes is hydraulic conductivity of plasma membrane. Unfortunately, there are only a few reports describing the direct influence of salt stress on the functional state of aquaporins. They include researches carried out on maize, which showed significant reduction in water movement through the plasma membrane in the salt stress conditions (Azaizeh et al. 1992).

Populus species (and hybrids), including poplar and natural salt tolerant Populus euphratica, are the model tree plants, and a lot of information about the influence of different stressors on their biochemistry, physiology, genetics, including molecular level are available (Chen et al. 2001; Han et al. 2013; Ma et al. 2002; Fischer and Polle 2010). Unfortunately, little is known about the influence of salt stress on this model woody plant on the single cell level in the aspect of physical properties of the plasma membrane and cell wall.

The objective of the present study was to evaluate the changes in cell turgor, hydraulic conductivity of plasma membrane and elastic modulus of the cell walls of parenchyma cells from leaf petiole of aspen hybrid in control plants and plants watered with $50 \mathrm{mM}$ solution of sodium chloride, to answer the question if there is any relationship between salt stress and physical properties of plasma membrane and cell wall. Moreover, the histology of leaf petiole and distribution of pectic epitopes recognised by JIM5 and JIM7 antibodies within the cell walls in control and treated plants were also investigated.

\section{Materials and methods}

Plant material and growth conditions

Production of sprout stems from the roots was carried out as follow, fragments of roots were transported to boxes filled with moist soil and grown in a growth chamber at $22{ }^{\circ} \mathrm{C}$ and $18 \mathrm{~h}$ light $/ 6 \mathrm{~h}$ dark photoperiod (such a photoperiod was necessary to obtain the sprout stems), irradiance of $40 \mu \mathrm{mol} \mathrm{m}{ }^{-2} \mathrm{~s}^{-1}$ and $80 \%$ of relative humidity. The soil was kept moist with demineralized water supplied with chloride-free fertilizer ( $1 \mathrm{~g} / 1 \mathrm{~L}$ Kristalon ${ }^{\mathrm{TM}}$ Green, YARA International; dissolved also in demineralized water). All measurements were performed on 8-month-old sprout stems during the two consecutive seasons, the year 2008 and 2009 and in the same laboratory. Sprout stems watered only with fertilizer made up the control group of plants, and were watered twice a week. Sprout stems treated up to 4 weeks with $50 \mathrm{mM}$ solution of sodium chloride 
(selection of $50 \mathrm{mM} \mathrm{NaCl}$ was based on preliminary experiments, where the influence of 50, 100 and $150 \mathrm{mM}$ $\mathrm{NaCl}$ solutions on plants was compared and showed that 100 and $150 \mathrm{mM}$ caused serious injuries to the stems) made up the salt-stressed group and were once a week watered with water supplemented with fertilizer and once a week with $\mathrm{NaCl}$ dissolved in demineralized water. In all cases, the amount of water/solution supplied to the pots was the same $(200 \mathrm{ml})$.

Petioles used directly in measurements were cut from 8-month-old sprout stems. All the investigated petioles were carefully derived from leaves that were almost at the same age (it was a leaf after which 12-16 new leaves were developed), so they were at the same stage of development during all the measurements. Cutting off petioles was each time conducted in the presence of water to prevent drying of injured tissues.

The tissue cell pressure probe (TCPP)

Turgor pressure in a single cortical cell of poplar petiole, hydraulic conductivity of plasma membrane and elastic modulus of the cell wall were measured by TCPP for higher plant cells (Steudle 1993).

The TCPP consists of the pressure chamber connected to the borosilicate glass microcapillary (with diameter about $10 \mu \mathrm{m}$, pulled into a fine point with an L/M-3P-A ListMedical Electronic Pipette Puller) and to the pressure transducer. The whole system is filled with silicone oil (relatively incompressible liquid that does not mix with the cell sap and creates a very good environment for pressure transducer to work properly). The volume and the pressure in chamber are regulated by means of a metal rod in the chamber connected to the micrometer screw. Detailed and excellent technical information on the use of the modern cell pressure probe are already published (Steudle 1993; Tomos and Leigh 1999).

The microcapillary can be inserted into the cell only with the aid of micromanipulator. Because of miniaturization of TCPP, the working station has to be supplied with high powered stereomicroscope and supplementary source of light to observe the meniscus in small capillary tip.

\section{The measurements}

Leaves with petioles were mounted on metal holder by plasticine to avoid movements of the petiole. The standard $(\mathrm{pH}=7.2)$ phosphate saline buffer (PBS) ran along the leaf with petiole using the circulating system kept by a peristaltic pump. A single cortical cell from the abaxial side of the petiole (about $1-2 \mathrm{~cm}$ from the stem) was punctured by oil-filled (silicone oil AS 4, Fluka, catalog No. 10833) microcapillary under the stereomicroscope
(Olympus SZX9) with the aid of a micromanipulator (Leica). After insertion of microcapillary into the cell, the cell sap entered the microcapillary and the cell sap/silicone oil meniscus was formed. The position of the meniscus was controlled by a piston modifying the volume of the system. Afterward the meniscus was gently adjusted to a position close to the cell by means of a motor to restore the sap volume close to the natural cell volume. The pressure was being increased via movement of the steel piston, so that the sap/oil meniscus was brought back to the surface of the cell. The pressure measured in the system at this point was equal to the turgor pressure of the cell prior to probe insertion (Steudle 1993).

By quick change of the cell volume (and according to this change-the change of cell turgor pressure) with the aid of the TCPP, the elastic modulus ( $\varepsilon$; which characterizes rigidity of cell wall) of individual cell was determined and calculated from (Eq. 1):

$\varepsilon=V \frac{\mathrm{d} P}{\mathrm{~d} V} \cong V \frac{\Delta P}{\Delta V}$

where $V$ is the cell volume and $P$ is the turgor pressure of this cell.

The elastic modulus represented the change in turgor pressure $(\Delta P)$ of the cell caused by a change of the cell volume $(\Delta V)$. The change in the cell volume $(\Delta V)$ was calculated from the movement of the meniscus in the capillary and from the capillary inner diameter. To evaluate $\varepsilon$, the cell volume $(V)$ was determined from the dimensions of the cells according to the previously described method (Meshcheryakov et al. 1992). The cell diameter and its length were measured from the cross and longitudinal sections of the petioles ( $n=100$ cells for each experimental group). The higher the values of $\varepsilon$ were obtained, the more the rigid cell walls were.

The hydraulic conductivity $\left(L_{\mathrm{p}}\right)$ was calculated according to Eq. 2:

$L_{\mathrm{p}}=\frac{V}{A} \frac{\ln 2}{T_{1 / 2}\left(\varepsilon+\pi^{i}\right)}$

where $A$ is the cell area, $T_{1 / 2}$ is a half-time of water exchange through the plasma membrane and $\pi^{i}$ is the osmotic pressure of the cell. The $L_{\mathrm{p}}$ was measured for control plants and plants treated with $\mathrm{NaCl}$ for 1 and 2 weeks.

The half-times of the water exchange were evaluated after adjustment of meniscus into a new position in capillary which corresponded to the changes in the turgor pressure. After such a shift, turgor pressure was changing exponentially with time and was approaching a new steady-state value. From these pressure-relaxation curves, half-times of water exchange through the plasma membrane were evaluated (Steudle 1993). All pressure 
Fig. 1 Average values of diameter and length (with SD) of cortical cells from Populus tremula $\times$ tremuloides petioles (for each group $n=100$ cells)

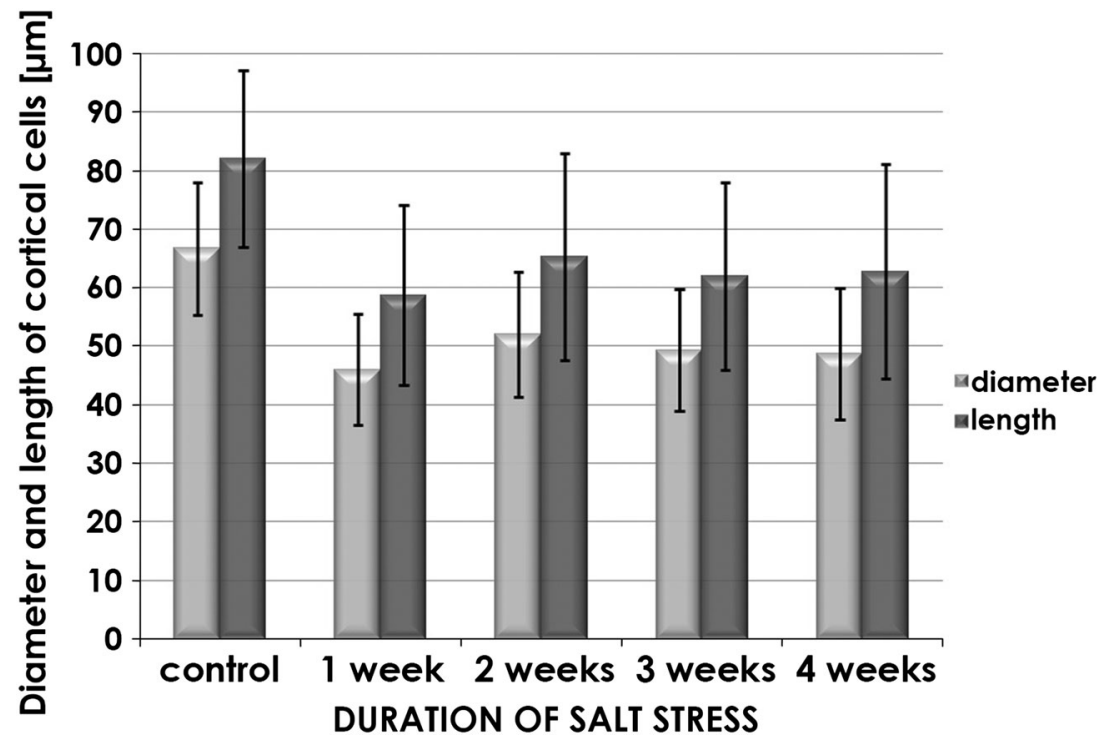

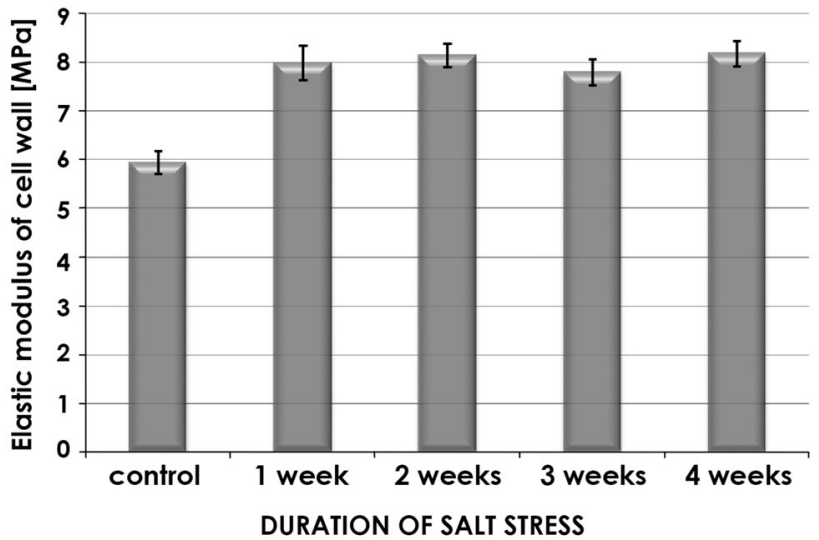

Fig. 3 Average values of elastic modulus of cell walls of control and salt stress cells $( \pm \mathrm{SD}$; number of examined cells $=15$ )

obtained values for control petioles in successive weeks, but measurements were performed in each time point of saline treatments.

\section{Histology of petioles}

Small fragments (approximately 2-3 $\mathrm{mm}$ ) of petioles from each experimental group were fixed in $2.5 \%$ glutaraldehyde in phosphate buffer at $\mathrm{pH}=7.2$, dehydrated in acetone series, embedded in Epon 812 resin (SigmaAldrich; Catalog No. 45345; 2007) and polymerized. After polymerization, samples were cut into a series of $5 \mu \mathrm{m}$ thick sections with the aid of microtome (Tesla BS 490A) and attached to glass slides on Haupt's adhesive. Afterward the sections were stained with PAS + toluidine blue, mounted with Euparal and analyzed in light microscope Olympus BX-41 equipped with a photo camera Olympus C-3040. 


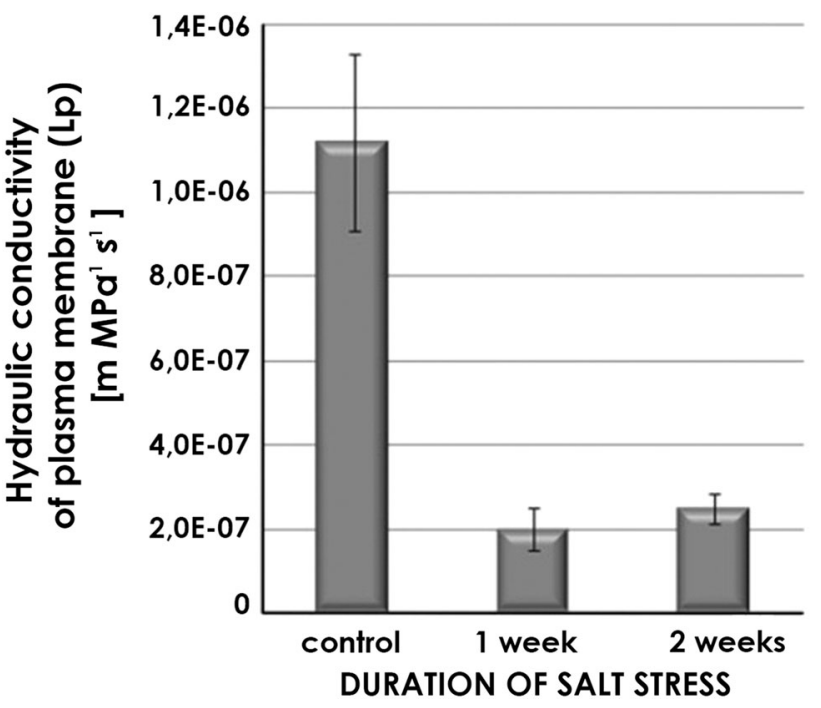

Fig. 4 Average values of hydraulic conductivity of plasma membrane $\left(L_{\mathrm{p}}\right)$ in increasing duration of salt stress

Immunolocalization of pectins

Petioles were fixed overnight at $4{ }^{\circ} \mathrm{C}$ in a mixture of $4 \%$ paraformaldehyde (Sigma-Aldrich, Catalog No. 158127; 2007) and $1 \%$ glutaraldehyde (Sigma-Aldrich, Catalog No. G5882; 2007) in PBS buffer at $\mathrm{pH}=7.2$ with addition of Triton X-100 (Fluka, Catalog No. 93420; 2007) dehydrated in an alcohol series and embedded in LR white embedding medium (Polysciences, Catalog No. 17411; 2005). Afterward samples were cut with the aid of ultramicrotome (Leica EM UC6) into a semi-thin sections $1 \mu \mathrm{m}$ thick and transferred on glass slides covered with polyL-lysine (Polysciences, Catalog No. 22247-1; 2005). Sections were immunolabeled overnight at $4{ }^{\circ} \mathrm{C}$ with JIM5 or JIM7 antibodies, next they were kept for $2 \mathrm{~h}$ at room temperature with another antibody conjugated with cyanine (both JIM5 and JIM7 were conjugated with cyanine dyes'), mounted in Gel-Mount (Sigma-Aldrich, Catalog No. G0918; 2007) and investigated with an epifluorescence microscope (Olympus BX-41 equipped with a photo camera Olympus C-3040).

\section{Results}

Histology and cell volume of parenchyma cells of Populus tremula $\times$ tremuloides petioles

Petioles of Aspen hybrid were flattened and covered by epidermis (Fig. 5). Under epidermis 5-6 layers of collenchyma were present. Xylem and sclerenchyma were located almost in the middle of the petiole and they were broken up into a number of slender strands around which parenchyma cells were located (Fig. 5). In general, no differences between the control and the treated plants in the histology of petioles were noticed. The only differences were the lowered diameter of petioles (however, statistical analysis was not performed) in salt-stressed plants and numerous intercellular spaces between parenchyma cells in the control plants which were not present in the plants treated with $\mathrm{NaCl}$ for 4 weeks.

An average diameter and length of the cortical cell from abaxial side of the petiole was determined by analysis of histological sections according to the previously described method (Mescheryakov et al. 1992). These dimensions were necessary to evaluate the cell volume. The cells from control plants had the largest average value both of the diameter and the length (Fig. 1). The differences between these cells and those treated with $\mathrm{NaCl}$ were not statistically significant, but a clear tendency to decrease in cell size in the plants treated with sodium chloride for weeks in comparison to the control plants is visible (Figs. 1, 5).

The average volume of the cortical cells found at abaxial side of the petiole was $10^{-13} \mathrm{~m}^{3}$. The volume of cells treated with $50 \mathrm{mM} \mathrm{NaCl}$ for $1,2,3$ and 4 weeks was: $0.98 \times 10^{-13}, 1.38 \times 10^{-13}, 1.18 \times 10^{-13}$ and $1.16 \times$ $10^{-13} \mathrm{~m}^{3}$, respectively.

\section{Turgor pressure}

Turgor pressure of cells from the control plants varied between 0.254 and $0.388 \mathrm{MPa}$. The average value was $0.3076 \mathrm{MPa}$ ( \pm 0.0377 , Fig. 2$)$. Turgor pressure reached the lowest value $(0.115-0.155 \mathrm{MPa})$ in the cells treated with salt solution for 1 week (average value reached $0.1324 \pm 0.0133 \mathrm{MPa}$, Fig. 2). After 2 weeks of salt stress turgor pressure increased to $0.251-0.298 \mathrm{MPa}$ (average: $0.269 \pm 0.0138 \mathrm{MPa}$, Fig. 2). Turgor pressure after next 2 weeks of the treatment with $\mathrm{NaCl}$ was stable and varied between 0.3 and $0.324 \mathrm{MPa}$ with average value of $0.3142 \mathrm{MPa}( \pm 0.0062 \mathrm{MPa}$, Fig. 2) after 3 weeks of salt stress and $0.315-0.334 \mathrm{MPa}$ after 4 weeks of treatment (average: $0.327 \pm 0.0059 \mathrm{MPa}$, Fig. 2).

\section{Cell wall elasticity}

Elastic modulus $(\varepsilon)$ measured for cells from the control plants ranged between 5.269 and $6.297 \mathrm{MPa}$ with the average value of $5.940 \mathrm{MPa}( \pm 0.231, n=15$ cells, Fig. 3). The values of $\varepsilon$ measured for plants treated with $\mathrm{NaCl}$ for 1 week ranged between 7.639 and $8.767 \mathrm{MPa}$ with an average value of $7.989 \mathrm{MPa}( \pm 0.354$, Fig. 3). The obtained differences in values of $\varepsilon$ for these two groups of plants were statistically significant $\left(\chi^{2}\right.$ test, $\left.p \leq 0.05\right)$. After 2 weeks of treatment with stressing factor, elastic modulus varied between 7.448 and $8.701 \mathrm{MPa}$ and the 
Fig. 5 a Cross section and histology of petioles of Populus tremula $\times$ tremuloides from control plant $($ bar $=300 \mu \mathrm{m})$; b cross section and histology of petioles of Populus tremulax tremuloides from plant treated for 4 weeks with $50 \mathrm{mM} \mathrm{NaCl}$ solution $($ bar $=300 \mu \mathrm{m})$; c fragment of petiole from the control plant showing the investigated cells

$($ bar $=150 \mu \mathrm{m}) ; \mathbf{d}$ fragment of petiole from plant treated for 4 weeks with $50 \mathrm{mM} \mathrm{NaCl}$ solution showing investigated cells $($ bar $=150 \mu \mathrm{m})$. $e$ epidermis, $c$ collenchyma, $p$ parenchyma, $s$ sclerenchyma, $v b$ vascular bundle, investigated cells marked with round bracket, $A B$ abaxial side of petiole, $A D$ adaxial side of petiole
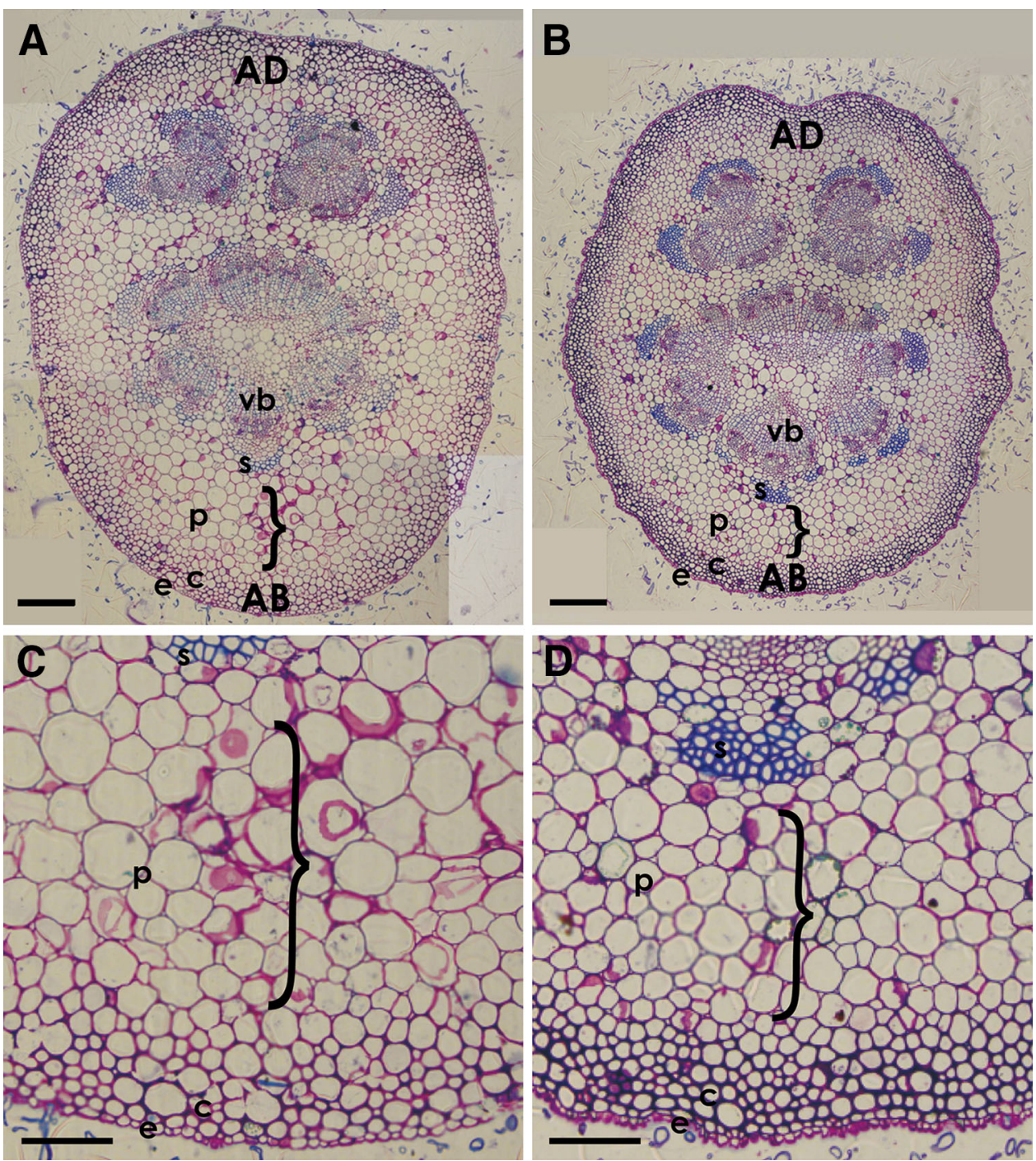

average value was $8.142 \mathrm{MPa}( \pm 0.242$; Fig. 3). After 3 weeks of salt stress, the value of elastic modulus ranged between 7.698 and $8.417 \mathrm{MPa}$ with an average value of $7.792 \mathrm{MPa}( \pm 0.274$, Fig. 3). Comparable data were obtained for plants treated with $\mathrm{NaCl}$ for 4 weeks. Namely, the values of elastic modulus ranged between 7.766 and 8.769 $\mathrm{MPa}$ with average value for this group equal to 8.176 MPa ( \pm 0.262 , Fig. 3).

\section{Hydraulic conductivity of plasma membrane}

Hydraulic conductivity in the cells from the control plants was rather high and equal to $1.12 \times 10^{-6} \mathrm{~m} \mathrm{MPa}^{-1} \mathrm{~s}^{-1}$ (Fig. 4). After a period of treatment with sodium chloride, the plants' $L_{\mathrm{p}}$ reduced drastically (Fig. 4). Namely, the average value of hydraulic conductivity after 1 week of treatment with $\mathrm{NaCl}$ was $0.2 \times 10^{-6}$ and $0.25 \times$ $10^{-6} \mathrm{~m} \mathrm{MPa}^{-1} \mathrm{~s}^{-1}$ after 2 weeks (Fig. 4). Differences between control plants and plants treated with $\mathrm{NaCl}$ for
1 and 2 weeks were statistically significant $\left(\chi^{2}\right.$ test, $p \leq 0.05)$.

Hydraulic conductivity in our experiment was not possible to measure during longer period of time up to 4 weeks, but if we extrapolate obtained results we get values as follow: $0.23 \times 10^{-6} \mathrm{~m} \mathrm{MPa}^{-1} \mathrm{~s}^{-1}$ after 3 weeks and $0.25 \times 10^{-6} \mathrm{~m} \mathrm{MPa}^{-1} \mathrm{~s}^{-1}$ after 4 weeks of salt stress. This indicates that the $L_{\mathrm{p}}$ is still lower in comparison to the control plant. Values obtained after extrapolation are similar to experimental values which were obtained for Arabidopsis (not published data) and also these values were lower.

Immunohistochemical localization of pectic epitopes recognised by JIM5 and JIM7 antibodies

In control plants, distribution of pectins recognised by JIM5 (low methylated pectins) antibody was rather regular within the cell wall except more intensive fluorescence in 
the middle lamella both in collenchyma and parenchyma cell walls (Fig. 61A, 3A). After 4 weeks of salt stress, epitopes recognized by JIM5 antibody were distributed quite regularly in the collenchyma and parenchyma cell walls and less visible in the middle lamella (Fig. 62A, 4A) in comparison to control plants.

Distribution of pectic epitope recognised by JIM7 (high methylated pectins) antibody in control plants was not regular within the cell walls of collenchyma (Fig. 61B). There were many spaces in younger layers of collenchyma walls without any fluorescence (Fig. 61B). The highest concentration of the epitopes recognized by JIM7 antibody was in the middle lamella (Fig. 61B). In the case of parenchyma walls these differences were not so visible, probably because of the wall thickness (Fig. 63B). In the salt-stressed plants after 4 weeks of treatment, the number of epitopes recognized by JIM7 in the youngest parts of collenchyma cell wall increased in comparison to control plants (Fig. 62B). In the case of parenchyma cells the most important differences between the control and stressed plants were presence of pectic epitopes recognised by JIM7 antibody within the cytoplasm (Fig. 63B, 4B).

\section{Discussion and conclusions}

Presented study was carried out to evaluate the changes in cell turgor, hydraulic conductivity of plasma membrane and elastic modulus of the cell walls of parenchyma cells from leaf petiole of aspen hybrid in control and saltstressed plants to answer the question if salinity influences physical properties of plasma membrane and cell wall at the individual cell level. The obtained results showed that in parenchyma cells from petioles with an increased level of $\mathrm{NaCl}$ in the soil: (a) turgor pressure was reduced after 1 week of treatment but afterward it was similar to untreated plants, (b) the value of elastic modulus of the cell walls increased, and (c) hydraulic conductivity of the plasma membrane of treated plants decreased in comparison to untreated ones. Analysis of the distribution within the cell walls of pectic epitopes recognised by JIM5 and JIM7 antibodies in control and salt-treated plants showed that in plants grown under salinity the presence of pectic epitopes recognized by JIM7 antibodies (which binds to methyl-esterified residues with adjacent or flanking unesterified GalA residues; Clausen et al. 2003) was increased in comparison to the control plants.

From many studies it is known that salt stress causes the reduction of plant growth (Munns and Tester 2008; Wrochna et al. 2006; Zhu 2002). In our studies we observed a subtle tendency to decrease the dimension of petiole parenchyma. It is postulated that efficient osmoregulation in leaves permits a drastic growth decrease and develops sufficient mechanical pressure for cell enlargement (Terry et al. 1983). We also observed a subtle decrease in petiole dimensions, but no histological differences between petioles of plants grown under salt stress and the controls were found apart from intercellular spaces similar to those observed in salt-stressed Spinacia oleracea leaves (Delfine et al. 1998). Authors concluded that in this case reduction of the intercellular spaces in the mesophyll tissue of salt-stressed plants could have caused a more tortuous path for $\mathrm{CO}_{2}$ directed toward the chloroplast and may be a cause of reduction of photosynthesis Delfine et al. (1998).

Many studies were performed on different plants including Populus euphratica, a natural salt tolerant plant of Populus genus, to explain the mechanism of salt tolerance in plants (Chen et al. 2001; Ma et al. 2002). Despite the increase in our knowledge about the changes which are taking place in plants under salt stress, still the mechanism is not completely understood especially on the cellular level (Lerner 1985; Molassiotis et al. 2006). According to our knowledge the results presented in this paper are the only ones describing the effect of salinity on the individual cells of aboveground parts of plant body in term of parameters controlling the movement of water across the plasma membrane and cell wall rigidity. The obtained results showed that the turgor pressure of cells from the plants treated with sodium chloride was almost twofold lower after 1 week of treatment in comparison to the control plants. The loss of turgor by cells under salinity was shown for some plants (Rygol and Zimmermann 1990). The decrease of the turgor after 1 week of salt treatment observed in these studies is comparable to the results obtained for the leaves of Asteriscus mauritimus (Rodríguez et al. 2005) or Brassica species (Singh et al. 2010), where the cell turgor pressure decreased after the treatment with sodium chloride. Lowering of the cell turgor pressure under salinity is probably caused by lower osmotic potential of salinized soil which leads to water decreasing in plant tissues. As long as the cell growth is correlated by turgor pressure in growing tissues, a low value of turgor is the main reason for the growth inhibition (Hock and Elstner 2004). The turgor is not always affected by salinity what was shown for Oryza sativa leaves (Yeo et al. 1991). The treatment of aspen hybrid with sodium chloride for longer time resulted in the "recovery" of turgor pressure of the stressed cells, and at the end of the experiments its value was comparable to that of the cells from the control plants. Such a reaction of plant to salinity can be interpreted as an adaptation to that kind of stress. It is difficult to compare the obtained results with literature as there is no information about the relationship between individual cell turgor pressure and salt stress. However, some information about general mechanisms of plant adaptation to salinity, including synthesis of some new proteins, amino acids, ion 

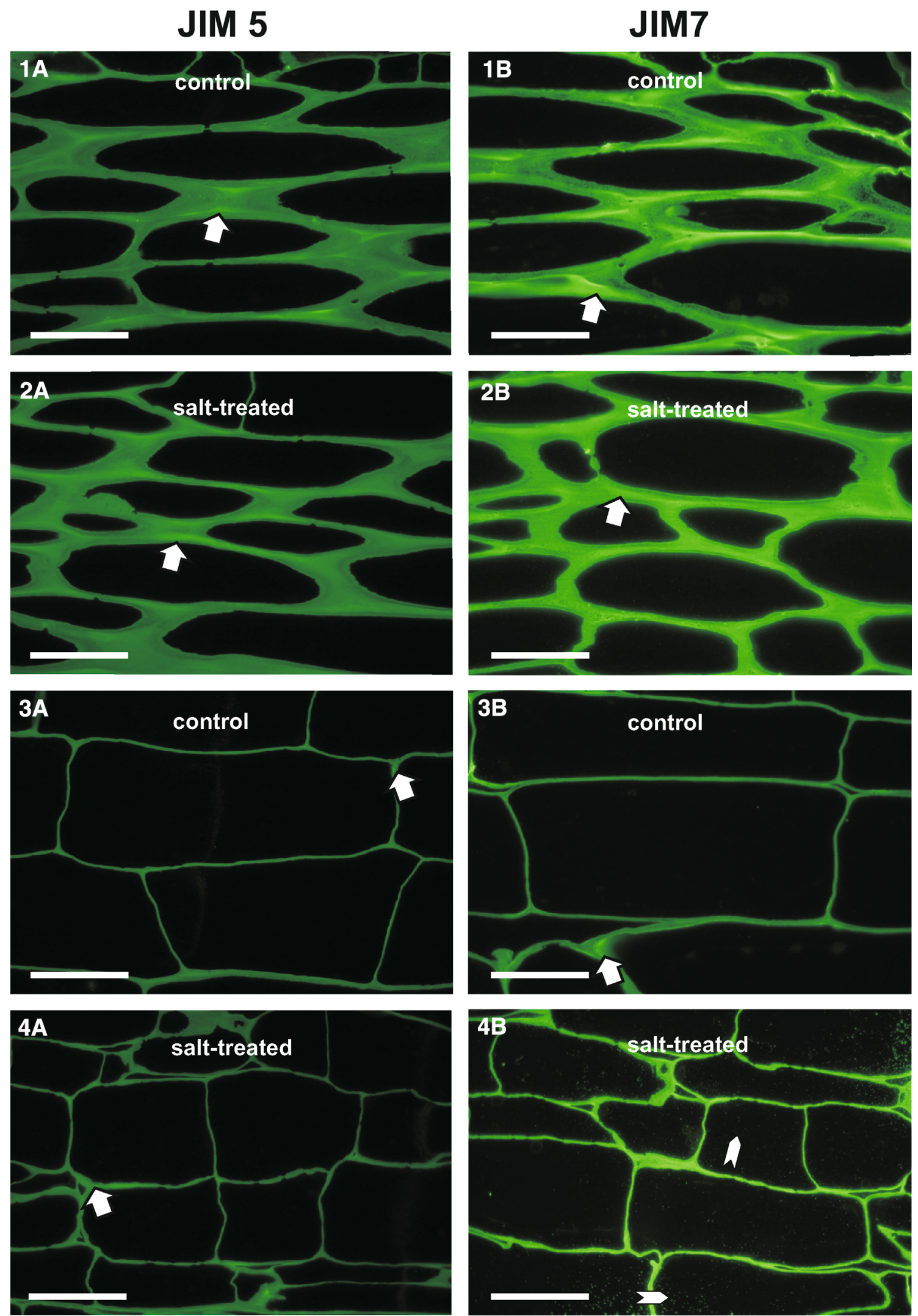
4Fig. 6 Distribution of pectic epitopes recognized by JIM5 and JIM7 antibodies on the longitudinal sections of poplar petiole in control and salt-stressed plants. 1A JIM5 epitopes in control collenchyma cells; 1B JIM7 epitopes in control collenchyma cells; 2A JIM5 epitopes in collenchyma cells after 4 weeks of salt stress; 2B JIM7 epitopes in collenchyma cells after 4 weeks of exposure to salt stress; 3A JIM5 epitopes in control parenchyma cells; 3B JIM 7 epitopes in control parenchyma cells; 4A JIM5 epitopes in parenchyma cells after 4 weeks of salt stress; 4B JIM7 epitopes in parenchyma cells after 4 weeks of salt stress; bar $=25 \mu \mathrm{m}$; arrowheads point to cytoplasmic presence of pectic epitopes; arrows point to cell wall with a presence of analyzed pectic epitopes

compartmentalization within the cell, is available (Mazel et al. 2004). It is postulated that in order to overcome the salinity stress plants developed at least two mechanisms: (1) salt is taken up by the cell and used as a major osmoticum, and (2) cell pumping out most of the salt that diffuses in, and osmotic stress is relieved by accumulation of organic solutes to maintain turgor (Lerner 1985). Which of these mechanisms operate in the case of aspen needs further studies.

Cell wall extensibility and cell turgor are two main features on which plant growth depends. It was shown that water potential and hydraulic conductivity of root are changed under salt stress impending water uptake by plants (Bolaños and Longstreth 1984). It was postulated that cell wall elasticity decreased under the salinity which allows the cell to maintain turgor or cell volume in response to water stress (Bolaños and Longstreth 1984). The observed in these studies increase (in comparison to control plants) of elastic modulus of walls from cells of plants grown under saline stress was visible already after 1 week of treatment and did not change during the experiment. The elastic modulus is a parameter which characterizes the wall rigidity - the higher is this value the less flexible is a cell wall (Steudle et al. 1977). It is possible that the increase of elastic modulus of cell walls is a reaction of plant to the growth in salinized soil and it is a kind of adaptation mechanism of plants to the growth under such a stress. It was observed that plant cell walls contract during osmotic dehydration (Marshall et al. 1999). It is postulated that cell wall can elastically constrict around a protoplast to regulate pressure and it is proposed as a mechanism explaining maintenance of turgor in shrunken tissues (Marshall et al. 1999). It is possible that the described in presented paper lowering of cell walls plasticity is necessary to maintain the turgor pressure at the proper level. Elastic alternation of cell wall permitted the root cells of Pinus banksiana to maintain the full turgor despite the loss of most water in the tissue (Marshall et al. 1999). The decrease of the cell wall elasticity (measured for the whole tissue) was detected in water stress experiments conducted on Spartina alterniflora (Hessini et al. 2009), Olea europaea (Dichio et al. 2003) and
Vitis vanifera (Schulz and Matthews 1993). It must be noted that the information available in the literature concerns cell wall elasticity with regard to the whole tissue and not to an individual cell. According to Dichio et al. (2003) high values of elastic modulus favor drought avoidance by stomatal control of transpiration for relatively small water losses and are beneficial when there is limited water (Dichio et al. 2003). Moreover, it is postulated that high values of elastic modulus and low values of osmotic potential are responsible for high water potential gradients between leaves and the soil and they facilitate water extraction from the soil (Dichio et al. 2003).

A cell wall is the place in the plant body where the response to environment is visible. The elasticity and plasticity of a cell depend on the composition and structure of the cell wall. It is known that salt stress causes reduction in the cell growth and suppresses the expression of genes involved in the loosening of plant cell walls (Ma and Bohnert 2007). It was suggested that the cell wall restructuring is a general adaptive mechanism during salinity stress in which activation of genes is changed (Ma and Bohnert 2007). Therefore, the changes in wall elasticity observed in this paper support the above mentioned hypothesis. The increase of highly methylated pectins that bind calcium ions and water less than low methyl-esterified pectins, which we observed in our studies, suggests that a cell wall is becoming more dehydrated during salt stress and supports the fact that there is decreased availability of water molecules in the plant during the salt stress. Pectin polysaccharides are also believed to play an important role in cell adhesion and tissue cohesion (McCartney and Knox 2002), which would be very important in plants that live in saline environments for adaptation to the stress.

Hydraulic conductivity of plasma membranes of cells from control plants was rather high and comparable to the results obtained for cortex of Pisum sativum (Cosgrove and Cleland 1983) and Glycine max (Steudle and Boyer 1985) hypocotyls, indicating that petiole cortex is a good water path for the cells located beneath epidermis. After 2 weeks of salt treatment hydraulic conductivity of cells was lower in comparison to the cells from the control plants. Low $L_{\mathrm{p}}$ means that water permeability through plasma membrane is reduced. A similar reduction of $L_{\mathrm{p}}$ was obtained for maize root cells (Azaizeh et al. 1992), melon root cells (Carvajal et al. 2000) and Arabidopsis thaliana (unpublished data). For some herbaceous plants it was shown that under salt stress, comparable in concentration to those used in the presented studies, root $L_{\mathrm{p}}$ was lowered which is interpreted as follows, the decrease of root $L_{\mathrm{p}}$ allows a higher transpiration rate, and together with higher $\mathrm{CO}_{2}$ assimilation rate plants reveal significant improvement under salinity stress (Sade et al. 2010). Decreasing of root $L_{\mathrm{p}}$ under salt stress was also noticed for some plants 
(Lopez-Berenguer et al. 2006). Root hydraulic conductivity can be also downregulated by water deficit (North et al. 2004).

Reduction in hydraulic conductivity undoubtedly represents stress-induced regulation of water transport in plants. It is believed that the increased osmotic pressure in the cell and in the apoplast surrounding protoplasts causes negative pressures in the pores of water channels that are affecting hydraulic conductivity (Ye et al. 2004). Reduction of hydraulic conductivity can be also considered as another aspect of adaptation to salt stress. We postulated that since water potential in soil is lowered, the reduction in hydraulic conductivity can facilitate retention of water in the cell and maintain turgor pressure. However, more experiments are needed to be performed to check how $L_{\mathrm{p}}$ of petiole cells changes during longer period of salinity at least as long as other measured parameters.

On the basis of the obtained results it can be concluded that salt stress increases the rigidity of plant cell walls and decreases the permeability of water through plasmalemma and does not influence the turgor. Changes in the cell wall flexibility might be one of the mechanisms of plant adaptation to the environmental stresses.

Authors contribution Aleksandra Muszynska-the main author, the analysis of the parameters describing the turgor pressure, elastic modulus of cell wall and hydraulic conductivity of plasma membrane. Histological analysis of the petiole, immunolocalization of JIM5, JIM7 in the cell wall and documentation. Analysis of the results and main contribution to the manuscript preparation.

Katarzyna Jarocka-measurements of the parameters describing the turgor pressure, elastic modulus of cell wall and hydraulic conductivity of plasma membrane, preparation of the sections and histological stainings of aspen hybrid petiole, immunolocalization of JIM5, JIM7 in the cell wall.

Ewa Kurczynska - the idea of the study, analysis of the results and contribution to the manuscript preparation.

\begin{abstract}
Acknowledgments We would like to thank Prof. Kazimierz Zajączkowski and Dr Krystyna Szczygieł from Forest Research Institute in Sękocin Stary (Poland), Department of Forest Genetics and Tree Physiology for providing an aspen hybrid Populus tremu$l a \times$ tremuloides roots. We are also very grateful to Prof. Paul Knox (University of Leeds, UK) and Dr Timothy Baldwin (University of Wolverhampton, UK) for JIM antibodies. Finally, we kindly thank Prof. Ernst Steudle ${ }^{\dagger}$ (University of Bayreuth, Germany) for introduction to TCPP technique and providing Pfloek program.
\end{abstract}

Open Access This article is distributed under the terms of the Creative Commons Attribution License which permits any use, distribution, and reproduction in any medium, provided the original author(s) and the source are credited.

\section{References}

Azaizeh H, Gunse B, Steudle E (1992) Effect of $\mathrm{NaCl}$ and $\mathrm{CaCl}_{2}$ on water transport across root cells of maize (Zea mays L.) seedlings. Plant Physiol 99:886-894

Bastías E, Fernández-García N, Carvajal M (2004) Aquaporin functionality in roots of Zea mays in relation to the interactive effects of boron and salinity. Plant Biol 6(4):415-421

Bolaños JA, Longstreth DJ (1984) Salinity effects on water potential components and bulk elastic modulus of Alternanthera philoxeroides (Mart.) Griseb. Plant Physiol 75:281-284

Boursiac Y, Chen S, Luu DT, Sorieul M, van den Dries N, Maurel C (2005) Early effects of salinity on water transport in Arabidopsis roots. Molecular and cellular features of aquaporin expression. Plant Physiol 139:790-805

Carvajal M, Cerdá A, Martínez V (2000) Does calcium ameliorate the negative effect of $\mathrm{NaCl}$ on melon root water transport by regulating aquaporin activity? New Phytol 145:439-447

Chen S, Li J, Wang S, Hüttermann A, Altman A (2001) Salt, nutrient uptake and transport, and ABA of Populus euphratica; a hybrid in response to increasing soil $\mathrm{NaCl}$. Trees 15:186-194

Chrispeels MJ, Maurel C (1994) Aquaporins: the molecular basis of facilitated water movement through living plant cells. Plant Physiol 105:9-13

Clausen MH, Willats WGT, Knox JP (2003) Synthetic methyl hexagalacturonate hapten inhibitors of antihomogalacturonan monoclonal antibodies LM7, JIM5 and JIM7. Carbohydr Res 338:1797-1800

Cosgrove DJ, Cleland RE (1983) Osmotic properties of pea internodes in relation to growth and auxin action. Plant Physiol 71:332-338

Cramer GR, Läuchli A (1986) Ion activities in solution in relation to $\mathrm{Na}^{+}-\mathrm{Ca}^{2+}$ interactions at the plasmalemma. J Exp Bot 37:321-330

Cramer GR, Epstein E, Läuchli A (1988) Kinetics of root elongation of maize in response to short-term exposure to $\mathrm{NaCl}$ and elevated calcium concentration. J Exp Bot 39(11):1513-1522

Dainty J, Ginzburg BZ (1964) The permeability of the protoplast of Chara australis and Nitella translucens to methanol, ethanol and iso-propanol. Biochim Biophys Acta 79:122-128

Delfine S, Alvino A, Zacchini M, Loreto F (1998) Consequences of salt stress on conductance to $\mathrm{CO}_{2}$ diffusion, Rubisco characteristics and anatomy of spinach leaves. Aust J Plant Physiol 25(3):395-402

Dichio B, Xiloyannis C, Angelopoulos K, Nuzzo VA, Bufo S, Celano G (2003) Drought-induced variations of water relations parameters in Olea europaea. Plant Soil 257(2):381-389

Fisher U, Polle A (2010) Populus responses to abiotic stress. In: Janson S, Bhalerao R, Groover A (eds) Genetics and genomics of populus. Springer, New York, pp 225-246

Han Y, Wang W, Sun J, Ding M, Zhao R, Deng S, Wang F, Hu Y, Wang Y, Lu Y, Du L, Hu Z, Diekmann H, Shen X, Polle A, Chen S (2013) Populus euphratica XTH overexpression enhances salinity tolerance by the development of leaf succulence in transgenic tobacco plant. J Exp Bot 64(14):4225-4238

Hasegawa PM, Bressan RA, Zhu JK, Bohnert HJ (2000) Plant cellular and molecular responses to high salinity. Annu Rev Plant Biol 51:463-499

Hessini K, Martínez JP, Gandour M, Albouchi A, Soltani A, Abdelly C (2009) Effect of water stress on growth, osmotic adjustment, cell wall elasticity and water-use efficiency in Spartina alterniflora. Environ Exp Bot 67(2):312-319

Hock B, Elstner EF (2004) Plant toxicology. Marcel Dekker, New York 
Lamport DTA, Kieliszewski MJ, Showalter AM (2006) Salt stress upregulates periplasmic arabinogalactan proteins: using salt stress to analyse AGP function. New Phytol 169:479-492

Lee SH, Singh AP, Chung GC, Ahn SJ, Noh EK, Steudle E (2004) Exposure of roots of cucumber (Cucumis sativus) to low temperature severely reduces root pressure, hydraulic conductivity and active transport of nutrients. Physiol Plant 120(3):413-420

Lerner HR (1985) Adaptation to salinity at the plant cell level. Plant Soil 89:3-14

Lopez-Berenguer C, Garcia-Viguera C, Carvajal M (2006) Are root hydraulic conductivity responses to salinity controlled by aquaporins in broccoli plants? Plant Soil 279:13-23

Luu DT, Maurel C (2005) Aquaporins in a challenging environment: molecular gears for adjusting plant water status. Plant Cell Environ 28:85-96

Ma S, Bohnert HJ (2007) Integration of Arabidopsis thaliana stressrelated transcript profiles, promoter structures, and cell-specific expression. Genome Biol 8(4):R49

Ma T, Liu Q, Li Z, Zhang X (2002) $\mathrm{H}^{+}$-ATPase in response to salt stress in Populus euphratica cell suspensions. Plant Sci 163:499-505

Marshall JG, Dumbroff EB, Thatcher BJ, Martin B, Rutledge RG, Blumwald E (1999) Synthesis and oxidative insolubilization of cell-wall proteins during osmotic stress. Planta 208(3):401-408

Martínez JP, Silva H, Ledent JF, Pinto M (2007) Effect of drought stress on the osmotic adjustment, cell wall elasticity and cell volume of six cultivars of common beans (Phaseolus vulgaris L.). Eur J Agron 26(1):30-38

Mazel A, Leshem Y, Tiwari BS, Levine A (2004) Induction of salt and osmotic stress tolerance by overexpression of an intracellular vesicle trafficking protein AtRab7 (AtRabG3e). Plant Physiol 134:118-128

McCann MC, Shi J, Roberts K, Carpita NC (1994) Changes in pectin structure and localization during the growth of unadapted and $\mathrm{NaCl}$-adapted tobacco cells. Plant J 5(6):773-785

McCartney L, Knox P (2002) Regulation of pectic polysaccharide domains in relation to cell development and cell properties in the pea testa. J Exp Bot 53(369):707-713

Meshcheryakov A, Steudle E, Komor E (1992) Gradients of turgor, osmotic pressure, and water potential in the cortex of the hypocotyl of growing Ricinus seedlings. Plant Physiol 98:840-852

Molassiotis A, Sotiropoulos T, Tanou G, Kofidis G, Diamantidis G, Therios E (2006) Antioxidant and anatomical responses in shoot culture of the apple rootstock MM 106 treated with $\mathrm{NaCl}, \mathrm{KCl}$, mannitol or sorbitol. Biol Plant 50(1):61-68

Munns R, Tester M (2008) Mechanisms of salinity tolerance. Annu Rev Plant Biol 59:651-681

Niu X, Bressan RA, Hasegawa PM, Pardo JM (1995) Ion homeostasis in $\mathrm{NaCl}$ stress environments. Plant Physiol 109:735-742

North GB, Martre P, Nobel PS (2004) Aquaporins account for variations in hydraulic conductance for metabolically active root regions of Agave deserti in wet, dry, and rewetted soil. Plant Cell Environ 27:219-228

Pérez-López U, Robredo A, Lacuesta M, Sgherri C, Mena-Petite A, Navari-Izzo F, Muñoz-Rueda A (2010) Lipoic acid and redox status in barley plants subjected to salinity and elevated $\mathrm{CO}_{2}$. Physiol Plant 139(3):256-268

Przedpełska E, Muszyńska A, Polatajko A, Kurczyńska EU, Wierzbicka M (2008) Influence of cadmium stress on aquaporins activity in Arabidopsis halleri (L.) O'Kane \& Al-Shehbaz ssp halleri cells. In: Collery P, Maymard I, Theophanides T, Khassanova L, Collery $\mathrm{T}$ (eds) Metal ions in biology and medicine, John Libbey Eurotext, Paris, 10:804-810

Rodríguez P, Torrecillas A, Morales MA, Ortuño MF, SánchezBlanco MJ (2005) Effects of $\mathrm{NaCl}$ salinity and water stress on growth and leaf water relations of Asteriscus maritimus plants. Environ Exp Bot 53(2):113-123

Rygol J, Zimmermann U (1990) Radial and axial turgor pressure measurements in individual root cells of Mesembryanthemum crystallinum grown under various saline conditions. Plant Cell Environ 13(1):15-26

Sade N, Gebretsadik M, Seligmann R, Schwartz A, Wallach R, Moshelion M (2010) The role of tobacco aquaporin1 in improving water use efficiency, hydraulic conductivity, and yield production under salt stress. Plant Physiol 152:245-254

Schulz HR, Matthews MA (1993) Xylem development and hydraulic conductance in sun and shade shoots of grapevine (Vitis vanifera L.): evidence that low light uncouples water transport capacity from leaf area. Planta 190:393-406

Singh P, Singh N, Sharma KD, Kuhad MS (2010) Plant water relations and osmotic adjustment in Brassica species under salinity stress. J Am Sci 6(6):1-4

Steudle E (1993) Pressure probe techniques: basic principles and application to studies of water and solute relations at the cell, tissue and organ level. In: Smith JAC, Griffiths H (eds) Water deficits: plant responses from cell to community. Bios Scientific Publishers, Oxford, pp 5-36

Steudle E, Boyer JS (1985) Hydraulic resistance to radial water flow in growing hypocotyl of soybean measured by a new pressureperfusion technique. Planta 164(2):189-200

Steudle E, Zimmermann U, Lüttge U (1977) Effect of turgor pressure and cell size on the wall elasticity of plant cells. Plant Physiol 59:285-289

Terry N, Waldron LJ, Taylor SE (1983) Environmental influences on leaf expansion. In: Dale JE, Milthorpe FL (eds) The growth and functioning of leaves. Cambridge University Press, Cambridge

Tomos AD, Leigh RA (1999) The pressure probe: a versatile tool in plant cell physiology. Annu Rev Plant Physiol Plant Mol Biol 50:447-472

Tournaire-Roux C, Sutka M, Javot H, Gout E, Gerbeau P, Luu DT, Bligny R, Maurel C (2003) Cytosolic pH regulates root water transport during anoxic stress through gating of aquaporins. Nature 425:393-397

Wrochna M, Gawrońska H, Gawroński SW (2006) Wytwarzanie biomasy i akumulacja jonów $\mathrm{Na}^{+}, \mathrm{K}^{+}, \mathrm{Ca}^{2+}, \mathrm{Mg}^{2+}, \mathrm{Cl}^{-} \mathrm{w}$ warunkach stresu solnego, przez wybrane gatunki roślin ozdobnych. Acta Agrophysica 7(3):775-785

Ye Q, Wiera B, Steudle E (2004) A cohesion/tension mechanism explains the gating of water channels (aquaporins) in Chara internodes by high concentration. J Exp Bot 396(55):449-461

Yeo AR, Lee KS, Izard P, Boursier PJ, Flowers TJ (1991) Short and long term effects of salinity on leaf growth in rice (Oryza sativa). J Exp Bot 42(7):881-889

Zhong H, Laüchli A (1993) Changes of cell wall composition and polymer size in primary roots of cotton seedlings under high salinity. J Exp Bot 44:773-778

Zhu J-K (2002) Salt and draught stress signal transduction in plants. Annu Rev Plant Biol 53:247-273 